\title{
IDENTIFYING THE CONNECT BETWEEN STUDENTS' SCIENCE ANXIETY LEVELS AND THEIR ACHIEVEMENT IN SCIENCE
}

\author{
Nitu Kaur* \\ *Department of Education, Mizoram University, Aizawl, Mizoram - 796 004, India \\ R.P. Vadhera* \\ *Department of Education, Mizoram University, Aizawl, Mizoram - 796 004, India
}

Article DOI: $\underline{\text { https://doi.org/10.36713/epra5912 }}$

\begin{abstract}
This study aims to explore the effect of an affective variable 'science anxiety' on students' achievement in science subject. By affective we refer to the learners' affect such as emotions, feelings, moods and attitudes involved in teaching-learning process. The chosen sample comprised of 1134 students (532 boys and 602 girls) of class X from 34 schools of Aizawl district of Mizoram. An adapted version of 'Science Anxiety Questionnaire' was used with some indigenous modifications to assess the level of science anxiety amongst the sample. The science anxiety scores of students were correlated with their science achievement scores obtained in class X board examination. Past researches have recognized 'science anxiety' as a negative affect responsible for student's underperformance in science. However, in the present finding the correlation coefficient value was found to be 0.1 indicating a very low but statistically significant positive relationship. This suggested that a minimum threshold level of science anxiety positively becomes the achievement in science. Anxiety levels were found to differ significantly between high and low science achievers, interestingly the high achievers (upper 27\%) were found to be more science anxious suggesting that the very low positive relationship between the science anxiety and science achievement of students was contributed more from the high achievers. The findings revealed a significant difference between science anxiety levels of boys and girls, the latter being more science anxious. The chi-square analysis also supported that science anxiety is not independent of gender.

KEYWORDS: Achievement in Science, Affect and Science, Science Anxiety, Secondary School Students
\end{abstract}

\section{INTRODUCTION}

If the discipline of science is characterized by logical processes, objective thinking, strong interconnections, evidence-based facts, does it also mean that while doing science one has to get rid of his/her belief system? Is science free from emotions? Is being rational equivalent to being emotionless? The western thought advocates a strong assumption that emotions threaten the disembodied, detached, and neutral knower hence they do not offer any valid knowledge which undermines the importance of emotions (Zembylas,
2005). School science is being portrayed as rational and non-emotional (Alsop, 2001; Zembylas, 2002). Science has been treated largely as a cognitive affair until recently when the connection between science and learner's affective domain has been reported in the literature. By affective we refer to the learners' affect such as emotions, feelings, moods and attitudes involved in the teaching learning process. Affect has the potential to influence the learner and thus science learning. Affect has to set the stage for learning to take place, just like the catalyst triggering the reaction. It 


\section{EPRA International Journal of Research and Development (IJRD)}

can both accelerate and retard the process of learning. Science education is not limited to cognition rather it becomes more meaningful when it targets the affect of the learners (Alsop \& Watts, 2003) but sadly it has given little attention to the emotions (Reiss, 2005). Students are seldom engaged entirely into learning when their affects are unfavourable. It decides the learners' readiness or remoteness for the learning process. Emotions can be positive or negative, desired or undesired, expressed or hidden and also at times stimulating or silent. Every action is a guided cognitive-affective phenomenon. Our emotions are our silent guardian and to a large extent, they control our behaviour. Several affect interplays in teachinglearning situation, inside a classroom and same implies to a science classroom. One of the affective variables very much a subject of concern over the last few decades in the field of science education which is also the main factor explored for the present study is "Science Anxiety". In 1977, Mallow coined the term "science anxiety" when he identified and defined the phenomenon observed within the clientele at Loyola University Counseling Center, Chicago, the first clinic of its kind to address the phenomenon (Mallow, 2010). Science anxiety is a fear or aversion toward science concepts, scientists, and science-related activities (Mallow, 1981). Mallow and Greenburg (1983) define science anxiety as "a diffuse or vague fear which arises in response to the prospect of learning science and results from intervening self-messages rather than from the science learning itself". Mallow (2010) further adds that science anxiety is "a debilitating interaction of emotion-fear, with cognition-science learning. It often manifests itself as a crippling panic on examinations in science classes, but it is distinct from general test/ performance anxiety." There is a difference between fear and anxiety. Fear deals with things which are generally phobic for majority like arachnophobia, fear of spiders; hydrophobia, fear of water whereas anxiety, on the other hand, is a fear of something self-contained within a person who feels anxious upon facing a situation, a person or a consequence. It is fearful for some and not for others. It means anxiety is varying phenomenon. Some people may be highly anxious, some moderately anxious and some may not be anxious at all for an existing situation or entity. Kastrup and Mallow (2016) explain this through a beautiful example, "Fear deals with things of which there is good reason to be afraid, such as a viper in your bed. Anxiety, on the other hand, means being scared of something that is not intrinsically fearful. Science anxiety is not a viper in your bed. But to a science-anxious person, it feels like it."(p. 3- 1)
Achievement in science is an overall reflection on learner's ability. How a child performs in sciences suggests how much potential he possesses for the future. Higher achievement in science is strongly associated with sound cognitive abilities of learners. It's a common assumption that facts are food for the brain and fuel the thinking process and especially in the context of the teaching-learning process of science subject facts play an exclusive role. Inside a science classroom, facts float and pour into the minds of the learner and much of this business is controlled by the science teachers. Are facts enough to develop the learner's potential in science? Why most students find science learning difficult as they proceed to higher grades? One must wonder if there are some missing ingredients in current school science recipes to address the declining interest of students towards higher sciences. Learners' affect involved in the teaching learning process has been overlooked to a great extent in the past, especially in the science classroom. Interestingly, Watts and Alsop (1997), states that their view particularly the conceptual change view of learning is dependent on the affective domain as much as on the cognitive. Therefore we believe it is indispensable to have a favourable affect within learners for enduring learning experiences. It is a prerequisite for students' engagement into learning, in absence of which meaningful, reliable, retainable and concept-change learning is hindered. Emotions contain useful information that can guide cognition and action (Izard, 2002). Students' emotional wellbeing is often the underlying cause of their interests in sciences and furthers their achievement in science. Emotions such as joy, love, happiness and hope, have a considerable influence over what happens in the classroom which acts to enhance education, optimise student enjoyment and achievement (Alsop, 2005). Generally, anxiety as an emotional state has been reported to have a negative association with students' achievement levels. Despite one's general desire to be less anxious facing various situational circumstances, it's a fact that anxiety is a very obvious biological and psychological phenomenon. Science anxiety has not been explored in Indian classroom setting so far but there is no doubt about its persistence among the students irrespective of their cultural and ethnic settings. It is confirmed through researches in the west that science anxiety interferes with one's performance in science indicative of a negative relationship between science anxiety and achievement. There are many causes of science anxiety including past bad experiences in science classes, science-anxious teachers in elementary and secondary schools, a lack of role models, gender and racial 


\section{EPRA International Journal of Research and Development (IJRD)}

stereotyping of scientists in the popular media (Kastrup \& Mallow, 2016). Whereas on the one hand it is assumed that science anxiety is one of the causes for students' underachievement in science, on the other hand, students' underachievement in science can be the cause for science anxiety. Present study aims to identify the connection between the student's science achievement and their level of science anxiety with the following research questions:

1. What is the level and nature of the distribution of science anxiety and academic achievement in science of secondary school students?

2. What is the impact of science anxiety on academic achievement of secondary school students in science?

3. What is the characteristic difference in science anxiety levels of high and low achievers in science at secondary school?

4. How does the gender of secondary school students influence their science anxiety and academic achievement in science?

\section{Sample and Population}

The chosen sample comprised of 1134 students (532 boys and 602 girls) of class X from 34 MBSE (Mizoram Board of School Education) affiliated schools in Aizawl district of Mizoram, India. All the MBSE affiliated secondary schools formed the population of the study. Stratified random sampling technique was used to pool out the sample.

\section{Sources of Data}

The present study has made use of both primary and secondary data. The primary data comprises of a sample of class $X$ students and secondary data comprised of data from annual publication on secondary schools, MBSE. The school visits were finalized using data from secondary sources. The class $\mathrm{X}$ board results of the sampled population were procured through MBSE office as the parameter of their science achievement.

\section{Instrument Used}

\section{Science Anxiety Questionnaire (SAQ)}

Here, we tried to adapt the science anxiety questionnaire to suit the indigenous requirement with the addition and deletion of some items as reported by a previous study (Czerniak \& Chiarelott, 1984). We tried to identify the possible dimensions for measurement of science anxiety taking an initial idea from earlier studies. The final Science Anxiety Questionnaire (SAQ) comprised of thirty items with six dimensions. Five Likert-type statements were framed under each dimension. Then they were arranged randomly. The objective was to assess the science anxiety levels under different dimensions. The respondents were expected to rate their response on a continuum ranging from "very relaxed", "relaxed", "neutral", "tensed" and "very tensed" by placing them in the frame of the feeling they experience as they read each statement. Each category was given a corresponding weight of $1,2,3,4, \& 5$. It was assumed that a greater degree of tension is perceived by those who are more science anxious and were given a high score on science anxiety. The concurrent criterion validity of the questionnaire used in the present study was found to be 0.68 with a previous study (Czerniak, \& Chiarelott, 1984). The reliability of the questionnaire with a test-retest method was found 0.87 with an approximate one month's gap. The Cronbach alpha coefficient for internal consistency on test and retest was found 0.86 and 0.88 respectively.

Dimensions of Science Anxiety: Studies indicate that science anxiety can be measured under certain dimensions (Czerniak \& Chiarelott, 1984; Kaya \& Yildirim, 2014). The present Science anxiety questionnaire has the following 6 dimensions:

Fear of testing. This dimension deals with the level of fear within the students displayed against any kind of testing such as class tests, monthly or weekly tests, annual exams, quizzing, explaining experiments in science labs.

Application of science: It assesses the feeling of students while performing some process skills in science lab.

Performance in front of others: It deals with the level of confidence within students, to handle lab equipment, working in front of masses etc.

Teachers' behaviour, teaching style and teaching environment. It assesses students' feelings about their science teachers' behaviour, teaching styles and science classroom environment .

Content mastery. It covers students' level of anxiety in terms of their reactions while mastering and applying science content.

Parents' expectation: This dimension relates to the feelings of the students against the attitude and expectations of their parents towards their science achievement.

The sampled students of Class X were given SAQ and asked to fill in their choices against the given items after explaining them the process of answering.

\section{DATA ANALYSIS \& STATISTICAL INTERPRETATION}

This section has been divided into three sections, namely the descriptive, correlational and differential analysis. 


\section{EPRA International Journal of Research and Development (IJRD)}

\section{Section-1: Descriptive Analysis}

We aimed to study the level and nature of the distribution of the variables chosen for the present study formulating the following objective:

Objective 1:
To figure out the level of science anxiety and science achievement amongst the secondary school students and to study the nature of the distribution of the scores in terms of skewness and kurtosis.

For the above-stated aim, we subjected the data to descriptive analysis and obtained important measures describing the sample (Table-1)

Table-1

Nature of Distribution of Scores of Achievement in Science (Dependent Variable) and Science Anxiety (Independent Variable) in Terms of Mean, Standard Deviation, Kurtosis And Skewness Values

\begin{tabular}{|c|c|c|c|c|c|c|c|c|c|}
\hline $\begin{array}{l}\text { Variable name } \\
(\mathrm{N}=1134) \text { with } \\
\text { range }\end{array}$ & Mean & SEM & SD & Kurtosis & $\begin{array}{c}\text { SEK } \\
\text { (standard } \\
\text { error of } \\
\text { kurtosis) }\end{array}$ & Skewness & $\begin{array}{c}\text { SES } \\
\text { (standa } \\
\text { rd error } \\
\text { of } \\
\text { skewne } \\
\text { ss) }\end{array}$ & $\begin{array}{l}\text { Normality test passing for } \\
\text { kurtosis and skewness } \\
\text { respectively(-1.96-+1.96) }\end{array}$ & $\begin{array}{c}\text { Whether } \\
\text { passed } \\
\text { normality? }\end{array}$ \\
\hline $\begin{array}{c}\text { Science Anxiety (30- } \\
150)\end{array}$ & 96.39 & .46 & 15.40 & 0.95 & 0.15 & -0.66 & 0.07 & $\begin{array}{l}6.53 \\
-9.09\end{array}$ & $\begin{array}{l}\text { NO, } \\
\text { NO }\end{array}$ \\
\hline $\begin{array}{c}\text { Science achievement } \\
\text { in Board Exam } \\
(0-100)\end{array}$ & 57.04 & .46 & 15.05 & -0.48 & 0.15 & 0.11 & 0.07 & $\begin{array}{c}-3.31 \\
1.5 \\
\end{array}$ & $\begin{array}{l}\text { NO, } \\
\text { YES }\end{array}$ \\
\hline
\end{tabular}

Source: Field data

Interpretation of Science Anxiety scores: The science anxiety score range is $30-150$ with least obtained score of 30 and maximum obtained score of 140. The mean value of the scores obtained from the sample population is 96.39 with SEM of 0.457 . The median value is 98 . The SD value is 15.40 . The skewness value $(-0.664)$ obtained reveals the negatively skewed nature of the distribution. This suggests that the level of science anxiety is towards the higher side in the sample population which is undesirable. The positive value of kurtosis (0.948) means that there is more data towards the tails and less data is in middle of the distribution i.e. it is leptokurtic.

Interpretation of Science Achievement scores: The science achievement score range is 0-100 (MBSE board) with least obtained score of 21 and maximum obtained score of 96 . The mean value of the scores obtained from the sample population is 57.04 with $\mathrm{SEM}$ of 0.447 . The median value is 56 . The SD value is 15.05 . The skewness value $(0.110)$ obtained reveals the slight positively skewed nature of the distribution. This suggests that the level of achievement in Science is moderately uniform with slightly more distribution of scores below the mean value which is acceptable for a population. The negative value of kurtosis $(-0.481)$ means that there is limited data towards the tails and more data is in middle of the distribution i.e. it is platykurtic.

\section{Section-2: Correlational Analysis}

This study aimed to understand and analyze the impact of science anxiety (independent variable) on the academic achievement of secondary school students in science (dependent variable). For that purpose following objective has been stated:

Objective 2:

To measure the impact of science anxiety on academic achievement of secondary school students in science.

To fulfill this objective the correlation analysis was performed between the assumed dependent and independent variables and Pearson's Correlation coefficient was obtained to be 0.1 (Table -2). 


\section{EPRA International Journal of Research and Development (IJRD)}

Table-2

Correlation between Achievement in Science (Dependent Variable) and Science Anxiety (Independent Variable)

\begin{tabular}{|c|c|c|c|c|c|c|}
\hline Independent variable & $\begin{array}{c}\text { Dependent } \\
\text { variable }\end{array}$ & $\mathbf{N}$ & Df & $\begin{array}{c}\text { Pearson's } \\
\text { Correlation } \\
\text { Coefficient }\end{array}$ & $\begin{array}{c}\text { Level of } \\
\text { Significance }\end{array}$ & S/NS \\
\hline Science Anxiety(SA) & $\begin{array}{c}\text { Science } \\
\text { Achievement } \\
\text { (Sci.Ach.) }\end{array}$ & 1134 & 1132 & 0.1 & 0.01 & $S^{*}$ \\
\hline
\end{tabular}

Source: Field data *extremely significant at 0.01 level

Interpretation of Correlation Coefficient: If we analyze the strength of the relationship it seems that the level of science anxiety of students is positively contributing to their science achievement with a low magnitude of 0.1 . Although very meagre, this impact of science anxiety on student's science achievement was found statistically significant at .01 level for the studied sample. The found value is desirable as a minimum level of anxiety is present even in high achievers. Past researches have recognized science anxiety as a negative affect responsible for student's underperformance in science. However, in the present study, the minimum but positive correlation is indicative of the fact that anxiety of any kind at its threshold and controlled level is very normal. Perhaps, it does not negatively contribute to one's achievement at its minimum level as it is a very natural phenomenon occurring within students due to lot many reasons. Since it has a biological as well as psychological basis it is not a disadvantage in most of the situations.

\section{Section 3: Differential analysis}

To find the answer to the third research question we formulated the following research objective.
Objective 3:

To compare the high and low achievers in science in relation to their science anxiety.

In this section, the data was subjected to differential analysis by applying student t-test (independent, unpaired) and chi-square test. We compared the data based on levels of science achievement, levels of science anxiety and gender. The research questions guided us to propose the null hypothesis which is as follows:

Ho:- There is no significant difference between high and low achievers in science with respect to science anxiety.

To identify the high and low achievers in the sample students' science achievement scores were arranged in descending order such that marks were arranged from highest to lowest. The upper $27 \%$ of the sample i.e. top 306 samples was identified as the high achievers and similarly the lower $27 \%$ of the sample i.e. the bottom 306 sample was identified as the low achievers. The science anxiety scores of the two groups were subjected to differential analysis. For the testing of hypothesis student ' $t$ ' test (independent sample) was performed (Table-3).

Table-3

Significance of difference between High and Low Achievers in Science in relation to their Science Anxiety

\begin{tabular}{|c|c|c|c|c|c|c|c|c|c|}
\hline Group & Number & $\begin{array}{c}\text { Mean } \\
(\mathbf{X})\end{array}$ & SD & SEM & $\begin{array}{c}\mathbf{t} \\
\text { alue }\end{array}$ & df & $\begin{array}{c}\text { Level of } \\
\text { Significance }\end{array}$ & S/NS & $\begin{array}{c}\text { Decision on Null } \\
\text { Hypothesis }\end{array}$ \\
\hline $\begin{array}{c}\text { High } \\
\text { Achievers }\end{array}$ & 306 & 97.56 & 14.26 & .82 & $3.90^{*}$ & 610 & 0.01 & $S^{*}$ & Rejected \\
\hline $\begin{array}{c}\text { Low } \\
\text { Achievers }\end{array}$ & 306 & 92.79 & 15.94 & .91 & & & & & \\
\hline
\end{tabular}

Source: Field data, *The test suggests that the difference between the two means is extremely significant at 0.01 level.

Interpretation of data: A reference to Table-3 reveals that there is statistically significant difference between the mean science anxiety scores of high achievers in science $(X=97.56, S D=14.26)$ and mean science anxiety scores of low achievers in science $(X=$ 92.79, $\mathrm{SD}=15.94$ ); the obtained $\mathrm{t}$ value (3.90) was found extremely significant at 0.01 level with degree of freedom 610, ' $t$ ' critical value (2.576) being < obtained ' $\mathrm{t}$ ' value. It means that science anxiety of secondary school students varies between low and high achievers. Hence the null hypothesis was rejected. Interestingly, 


\section{EPRA International Journal of Research and Development (IJRD)

the science anxiety of high achievers is greater than that of low achievers.

A further analysis was performed where we segregated the students' science anxiety scores into three levels. For this purpose 'bucket analysis' technique was applied taking the idea from Kastrup \& Mallow (2016). The science anxiety scores of students ranging from 30-150 were divided into three categories with scores from 30-70 revealing low, 71-110 revealing moderate and 111-150 revealing high science anxiety level.
A comparison of mean science scores of low, moderate and high anxiety group (Figure 1) revealed that both moderate and high anxious groups showed better performance in science compared to low anxious group found significant at 0.01 level. However, between the moderate and high anxious group, where the later has a higher mean score, the difference is insignificant at 0.01 level. This finding is interesting indicating the existence of science anxiety in high anxious groups may have positively contributed to perform better in science and overall achievement than the low anxious group.

Figure 1: Mean science marks in low (green 51.03), moderate (blue 57.31) and high (red 58.02) anxiety groups (SEM 1.93, $0.51 \& 0.98$ respectively for low, moderate and high anxiety group)

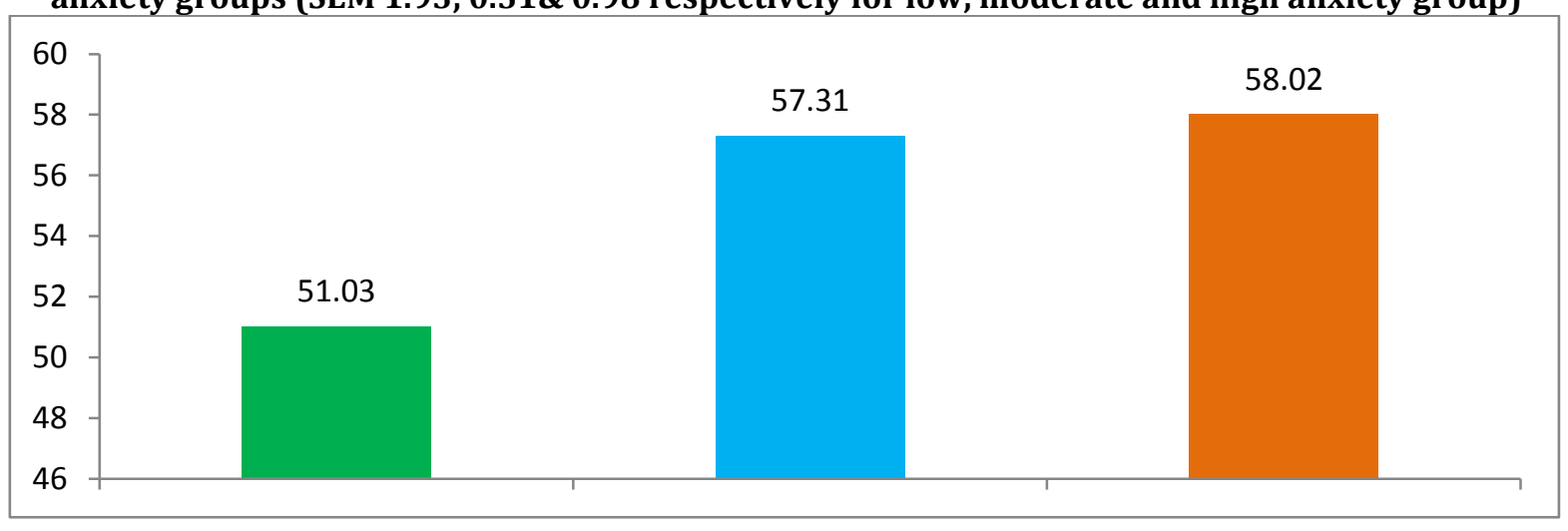

Further we analyze the differences between high and low achievers in science with respect to the six dimensions against which science anxiety of students was measured using Science Anxiety Questionnaire (SAQ). As already mentioned under every dimension five items were kept making a total of thirty items. Each dimension has a score range of 5-25. We segregated the low, moderate and high anxiety scores for each dimension with scores between 5-11, 12-18 \&19-25 respectively. Frequency distribution of the different anxiety levels on each dimension was analyzed using percentages (Figure 2). The findings revealed that except 'Fear of Testing' dimension on all other dimensions students were found to be moderately science anxious. On this dimension students with high science anxiety $(49.20 \%)$ and with moderate science anxiety $(45.06 \%)$ together accounted for $94.3 \%$ of the total sample population. It means 'fear of testing' dimension contributed maximally to their science anxiety. 


\section{EPRA International Journal of Research and Development (IJRD)}

Volume: 5 | Issue: 12 | December 2020

- Peer Reviewed Journal

Figure 1: A comparative description of frequency distribution of science anxiety level of students as measured against the its six dimensions.

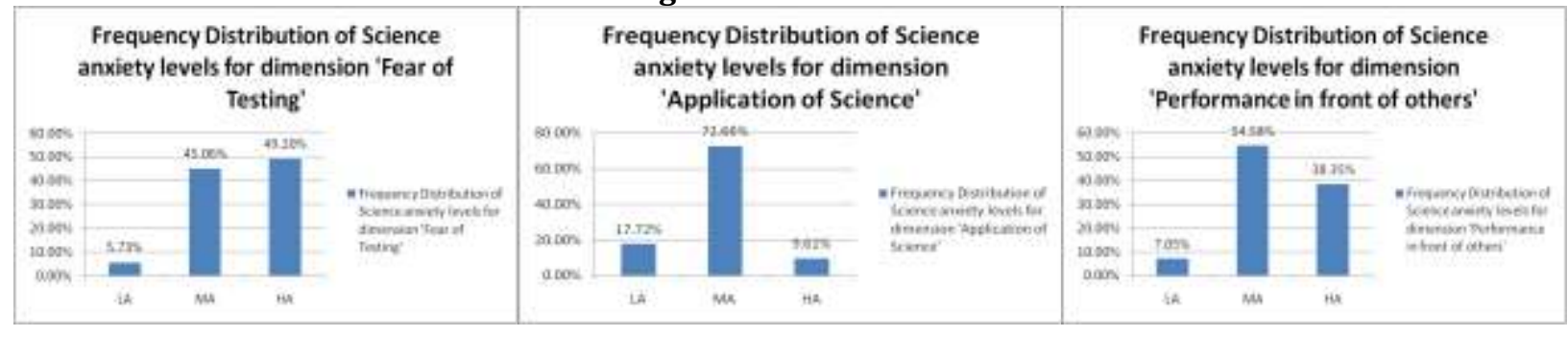

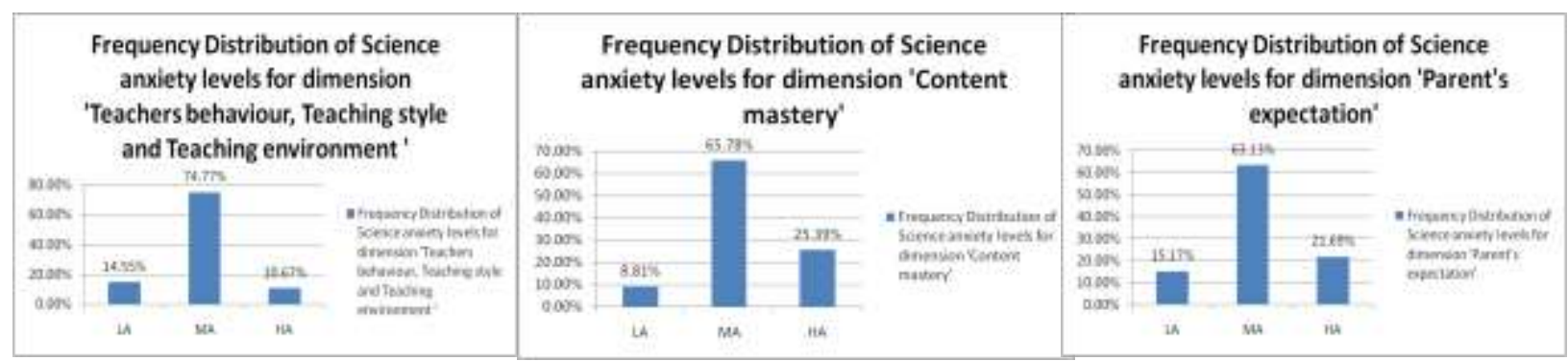

Further, student t-test (independent) was performed to compare the high and low science achievers for their science anxiety levels on each dimension. For testing following null hypotheses were proposed.

Ho1:- There is no significant difference between high and low achievers in science with respect to science anxiety measured through the dimension 'fear of testing

Ho2:- There is no significant difference between high and low achievers in science with respect to science anxiety measured through the dimension 'application of science'

Ho3:- There is no significant difference between high and low achievers in science with respect to science anxiety measured through the dimension 'performance in front of others'

Ho4:- There is no significant difference between high and low achievers in science with respect to science anxiety measured through the dimension 'Teachers' behaviour, teaching style and teaching environment'

Ho5:- There is no significant difference between high and low achievers in science with respect to science anxiety measured through the dimension 'Content mastery'

Ho6:- There is no significant difference between high and low achievers in science with respect to science anxiety measured through the dimension 'Parents' expectation'

Table-4 depicts the results of the hypothesis testing.

Table-4

Significance of difference between High and Low Achievers in Science in relation to their means on different dimensions of Science anxiety

\begin{tabular}{|c|c|c|c|c|c|c|c|c|c|c|}
\hline Dimensions & Groups & Number & $\begin{array}{l}\text { Mean } \\
\text { (X) }\end{array}$ & S.D. & SEM & $\begin{array}{c}\text { t } \\
\text { value }\end{array}$ & Df & $\begin{array}{l}\text { Level of } \\
\text { Significa } \\
\text { nce }\end{array}$ & S/NS & $\begin{array}{c}\text { Decision on } \\
\text { Null } \\
\text { Hypothesis }\end{array}$ \\
\hline \multirow[t]{2}{*}{ 1. Fear of testing } & $\begin{array}{c}\text { High } \\
\text { achievers in } \\
\text { Science } \\
\end{array}$ & 306 & 19.23 & 3.49 & 0.19 & \multirow[t]{2}{*}{$9.28^{*}$} & \multirow[t]{2}{*}{610} & \multirow[t]{2}{*}{0.01} & \multirow[t]{2}{*}{$\mathrm{S}^{*}$} & \multirow[t]{2}{*}{$\begin{array}{c}\text { Ho1 } \\
\text { Rejected }\end{array}$} \\
\hline & $\begin{array}{l}\text { Low } \\
\text { achievers in } \\
\text { Science }\end{array}$ & 306 & 16.51 & 3.76 & 0.21 & & & & & \\
\hline \multirow[t]{2}{*}{$\begin{array}{l}\text { 2. Application of } \\
\text { Science }\end{array}$} & $\begin{array}{c}\text { High } \\
\text { ievers in Science }\end{array}$ & 306 & 13.65 & 3.03 & 0.17 & \multirow[t]{2}{*}{$4.69^{*}$} & \multirow[t]{2}{*}{610} & \multirow[t]{2}{*}{0.01} & \multirow[t]{2}{*}{$\mathrm{S}^{*}$} & \multirow[t]{2}{*}{$\begin{array}{c}\text { Ho2 } \\
\text { Rejected }\end{array}$} \\
\hline & Low achievers & 306 & 14.87 & 3.41 & 0.19 & & & & & \\
\hline
\end{tabular}


SJIF Impact Factor: 7.001| ISI I.F.Value:1.241| Journal DOI: 10.36713/epra2016 ISSN: 2455-7838(Online)

EPRA International Journal of Research and Development (IJRD)

Volume: 5 | Issue: 12 | December 2020

- Peer Reviewed Journal

\begin{tabular}{|c|c|c|c|c|c|c|c|c|c|c|}
\hline & in Science & & & & & & & & & \\
\hline \multirow[t]{2}{*}{$\begin{array}{l}\text { 3. Performance in } \\
\text { front of Others }\end{array}$} & $\begin{array}{l}\text { High achievers } \\
\text { in Science }\end{array}$ & 306 & 17.79 & 3.47 & 0.19 & \multirow[t]{2}{*}{$6.08^{*}$} & \multirow[t]{2}{*}{610} & \multirow[t]{2}{*}{0.01} & \multirow[t]{2}{*}{$\mathrm{S}^{*}$} & \multirow[t]{2}{*}{$\begin{array}{c}\text { Ho3 } \\
\text { Rejected }\end{array}$} \\
\hline & $\begin{array}{l}\text { Low achievers } \\
\text { in Science }\end{array}$ & 306 & 15.99 & 3.87 & 0.2211 & & & & & \\
\hline \multirow{2}{*}{$\begin{array}{c}\text { 4. Teachers' } \\
\text { behaviour, } \\
\text { teaching style and } \\
\text { teaching } \\
\text { environment }\end{array}$} & $\begin{array}{l}\text { High achievers } \\
\text { in Science }\end{array}$ & 306 & 14.60 & 2.83 & 0.16 & \multirow[t]{2}{*}{0.93} & \multirow[t]{2}{*}{610} & \multirow[t]{2}{*}{0.05} & \multirow[t]{2}{*}{ NS } & \multirow[t]{2}{*}{$\begin{array}{c}\text { Ho4 } \\
\text { Accepted }\end{array}$} \\
\hline & $\begin{array}{l}\text { Low achievers } \\
\text { in Science }\end{array}$ & 306 & 14.38 & 3.14 & 0.18 & & & & & \\
\hline \multirow[t]{2}{*}{ 5. Content mastery } & $\begin{array}{l}\text { High achievers } \\
\text { in Science }\end{array}$ & 306 & 16.21 & 3.21 & 0.18 & \multirow[t]{2}{*}{$2.59^{*}$} & \multirow[t]{2}{*}{610} & \multirow[t]{2}{*}{0.01} & \multirow[t]{2}{*}{$\mathrm{S}^{*}$} & \multirow[t]{2}{*}{$\begin{array}{c}\text { Ho5 } \\
\text { Rejected }\end{array}$} \\
\hline & $\begin{array}{l}\text { Low achievers } \\
\text { in Science }\end{array}$ & 306 & 15.51 & 3.46 & 0.19 & & & & & \\
\hline \multirow[t]{2}{*}{ 6. Parents' expectation } & $\begin{array}{l}\text { High achievers } \\
\text { in Science }\end{array}$ & 306 & 15.84 & 3.83 & 0.22 & \multirow[t]{2}{*}{1.08} & \multirow[t]{2}{*}{610} & \multirow[t]{2}{*}{0.05} & \multirow[t]{2}{*}{ NS } & \multirow[t]{2}{*}{$\begin{array}{c}\text { Ho6 } \\
\text { Accepted }\end{array}$} \\
\hline & $\begin{array}{l}\text { Low achievers } \\
\text { in Science }\end{array}$ & 306 & 15.52 & 3.74 & 0.21 & & & & & \\
\hline
\end{tabular}

Source: Field data

Interpretation of data: A reference to Table-4 shows that for four dimensions of SAQ there is statistically significant difference between the mean science anxiety scores of high and low achievers in science: Fear of testing $[\mathrm{t}(610)=9.28, \quad \mathrm{p}<.0 .01)], \quad$ Application of science $[\mathrm{t}(610)=4.69, \mathrm{p}<.0 .01)]$, Performance in front of others $[\mathrm{t}(610)=6.08, \mathrm{p}<.0 .01)]$ and Content mastery $[\mathrm{t}(610)=2.59, \mathrm{p}<.0 .01)]$. On these dimensions, high achievers are found more anxious except the dimension 'application of science' on which low achievers are found more anxious. However, there is no significant difference between the mean scores for two dimensions of SAQ: Teachers' behaviour, teaching style and teaching environment $[(\mathrm{t}(610)=0.93, \mathrm{p}>.05)]$ and
Parents' expectation $[(\mathrm{t}(610)=1.08, \mathrm{p}>.05)]$. Hence Ho1, Ho2, Ho3, Ho5 were rejected and Ho4, Ho6 were accepted.

The last research question guided us to formulate the following research objectives which we subjected to differential analysis.

Objective 4:

To compare the gender variation in science anxiety amongst secondary school students.

Following null hypotheses were proposed

Ho:- There is no significant gender difference in secondary school students with respect to their science anxiety. For the testing of hypothesis student ' $\mathrm{t}$ ' test (independent sample) was performed (Table-5)

Table-5

Significance of difference between Boys and Girls in relation to their Science Anxiety

\begin{tabular}{|c|c|c|c|c|c|c|c|c|c|}
\hline Group & Number(N) & $\begin{array}{c}\text { Mean } \\
\text { (X) }\end{array}$ & SD & SEM & t value & Df & $\begin{array}{c}\text { Level of } \\
\text { Significance }\end{array}$ & $\begin{array}{c}\text { Decision on } \\
\text { Null Hypothesis }\end{array}$ \\
\cline { 1 - 6 } Boys & 532 & 94.84 & 14.93 & .65 & $3.21^{*}$ & 1132 & 0.01 & Rejected \\
\hline Girls & 602 & 97.77 & 15.68 & .64 & & \\
\hline
\end{tabular}

Source: Field data. *The test suggests that the difference between the two means is highly significant at 0.01level.

Interpretation of data: A reference to Table-5 reveals that the obtained $t$ value (3.21) was found significant at 0.01 level with a degree of freedom 1132 , ' $\mathrm{t}$ ' critical value(2.576) being < obtained ' $\mathrm{t}$ ' value. It means that science anxiety of secondary school students vary with respect to their gender and girls were found to be more science anxious. Hence the null hypothesis was rejected. Further $\mathrm{X} 2$ results for test of independence between gender and the three levels of science anxiety was also performed with the following null hypothesis.

Ho:- There is no significant association between gender and level of science anxiety. 


\section{EPRA International Journal of Research and Development (IJRD)}

Table-6

$\chi^{2}$ results for test of independence between Gender and level of Science Anxiety

\begin{tabular}{|c|c|c|c|c|c|c|}
\hline Group & High Anxiety & $\begin{array}{l}\text { Moderate } \\
\text { Anxiety }\end{array}$ & $\begin{array}{c}\text { Low } \\
\text { Anxiety }\end{array}$ & Total & $\begin{array}{c}\text { Level of } \\
\text { Significa } \\
\text { nce }\end{array}$ & $\begin{array}{c}\text { Decision on } \\
\text { Null Hypothesis }\end{array}$ \\
\hline Boys & $\begin{array}{c}\text { Obs. } 66 \\
(\exp .87 .72)\end{array}$ & $\begin{array}{c}\text { Obs. } 431 \\
(\exp .410 .96)\end{array}$ & $\begin{array}{c}\text { Obs. } 35 \\
\text { (exp.33.31) }\end{array}$ & 532 & \multirow{6}{*}{0.01} & \multirow{6}{*}{ Rejected } \\
\hline $\mathbf{F}_{\mathbf{0}}-\mathbf{F}_{\mathbf{e}}$ & -21.72 & 20.04 & 1.69 & & & \\
\hline Girls & $\begin{array}{c}\text { Obs. } 121 \\
\text { (exp.99.27) }\end{array}$ & $\begin{array}{c}\text { Obs. } 445 \\
(\exp .465 .03)\end{array}$ & $\begin{array}{c}\text { Obs. } 36 \\
\text { (exp.37.69) }\end{array}$ & 602 & & \\
\hline$F_{0}-F_{e}$ & 21.73 & -20.03 & -1.69 & & & \\
\hline Total & 187 & 876 & 71 & 1134 & & \\
\hline$\chi^{2}=\left(F_{0}-F_{e}\right)^{2} / F_{e}$ & \multicolumn{4}{|c|}{$5.38+4.76+0.98+0.86+0.09+0.08=12.15 *(d f=2)$} & & \\
\hline
\end{tabular}

Source: Field data.

Interpretation of data: The chi-square analysis (Table-6) shows that science anxiety is not independent of gender. The obtained chi-square value of 12.15 was found highly significant at 0.01 level at $2 \mathrm{df}$, ' $\mathrm{X} 2$ ' critical value $(9.210)$ being $<$ obtained $X$ 2value indicating that there is a significant association between the different levels of science anxiety and gender. Hence the null hypothesis was rejected.
Objective 5:

To compare the gender variation in science achievement amongst the secondary school student.

For the given objective the science achievement scores of students were compared with respect to their gender. Following null hypothesis was proposed:

Ho:- There is no significant gender difference in secondary school students with respect to science achievement.

For the testing of hypothesis student ' $\mathrm{t}$ ' test (independent sample) was performed (Table-7).

Table-7

Significance of Difference between Boys and Girls in Relation to their Achievement in Science

\begin{tabular}{|c|c|c|c|c|c|c|c|c|c|}
\hline Group & Number & $\begin{array}{l}\text { Mean } \\
(\mathrm{X})\end{array}$ & SD & SEM & $\begin{array}{r}\mathbf{t} \\
\text { alue }\end{array}$ & Df & $\begin{array}{c}\text { Level of } \\
\text { Significance }\end{array}$ & S/NS & $\begin{array}{l}\text { Decision } \\
\text { on } \\
\text { Null } \\
\text { Hypothesi } \\
\text { s }\end{array}$ \\
\hline Boys & 532 & 58.75 & 14.32 & .621 & \multirow[t]{2}{*}{$3.62^{*}$} & \multirow[t]{2}{*}{1132} & \multirow[t]{2}{*}{0.01} & \multirow[t]{2}{*}{$\mathrm{S}^{*}$} & \multirow[b]{2}{*}{ Rejected } \\
\hline Girls & 602 & 55.52 & 15.51 & .632 & & & & & \\
\hline
\end{tabular}

Interpretation of data: A reference to Table-7 reveals that the obtained $t$ value (3.62) was found significant at 0.01 level with a degree of freedom 1132 , ' $\mathrm{t}$ ' critical value(2.576) being < obtained ' $\mathrm{t}$ ' value. It means that the science achievement of secondary school students varies with respect to their gender. The science achievement of boys is better than girls. Hence the null hypothesis was rejected.

Objective 6:

To compare the gender variation on science anxiety amongst secondary school students within high and low achievers in science.

The science achievement scores were used as a grouping variable. The high and low achievers in science were selected comprising of 306 students each (upper and lower 27\%). The science anxiety scores of the two groups were pooled out and further within high and low achievers gender comparison was done. Following null hypotheses were proposed;

Ho1:-There is no significant difference between high achieving boys and high achieving girls of secondary school students with respect to science anxiety.

Ho2:-There is no significant difference between low achieving boys and low achieving girls of the secondary school students with respect to science anxiety.

For the testing of hypothesis student ' $\mathrm{t}$ ' test (independent sample) was performed (Table-8). 


\section{EPRA International Journal of Research and Development (IJRD)}

Table-8

Gender differences in High and Low Achievers in Science in relation to their Science Anxiety(SA)

\begin{tabular}{|c|c|c|c|c|c|c|c|c|c|}
\hline Group & Number & $\begin{array}{c}\text { Mean } \\
\text { (X) }\end{array}$ & SD & SEM & T value & Df & $\begin{array}{c}\text { Level of } \\
\text { Significance }\end{array}$ & S/NS & $\begin{array}{l}\text { Decision on } \\
\text { Null } \\
\text { Hypothesis }\end{array}$ \\
\hline $\begin{array}{r}\text { SA of High } \\
\text { Achieving Boys }\end{array}$ & 156 & 95.44 & 14.70 & 1.18 & \multirow[t]{2}{*}{2.678} & \multirow[t]{2}{*}{304} & \multirow[t]{2}{*}{0.01} & \multirow[t]{2}{*}{$\mathrm{S}^{*}$} & \multirow[t]{2}{*}{$\begin{array}{c}\text { Ho1 } \\
\text { Rejected }\end{array}$} \\
\hline $\begin{array}{r}\text { SA of High } \\
\text { Achieving Girls }\end{array}$ & 150 & 99.76 & 13.49 & 1.10 & & & & & \\
\hline $\begin{array}{r}\text { SA of Low } \\
\text { Achieving Boys }\end{array}$ & 120 & 93.07 & 13.90 & 1.27 & \multirow[t]{2}{*}{0.246} & \multirow[t]{2}{*}{304} & \multirow[t]{2}{*}{0.05} & \multirow[t]{2}{*}{ NS } & \multirow[t]{2}{*}{$\begin{array}{c}\text { Ho2 } \\
\text { Accepted }\end{array}$} \\
\hline $\begin{array}{c}\text { SA of Low } \\
\text { Achieving Girls }\end{array}$ & 186 & 92.61 & 17.16 & 1.26 & & & & & \\
\hline
\end{tabular}

Source: Field data

Interpretation of data: A reference to Table- 8 reveals that there is statistically significant difference between the mean science anxiety scores of boys $(\mathrm{X}=$ 95.44, $\mathrm{SD}=14.70)$ and $\operatorname{girls}(\mathrm{X}=99.76, \mathrm{SD}=13.49)$ within the high achieving groups; the obtained $t$ value (2.678) was found significant at 0.01 level with degree of freedom 304, ' $\mathrm{t}$ ' critical value(2.576) being < obtained ' $\mathrm{t}$ ' value. It means that there was variation in science anxiety levels of students within the high achieving groups with respect to their gender. The level of science anxiety is found higher in girls compared to boys. Hence the null hypothesis (Ho1) was rejected. However, there was no statistically significant difference found between the mean science anxiety scores of $\operatorname{boys}(\mathrm{X}=93.07, \mathrm{SD}=13.90)$ and $\operatorname{girls}(\mathrm{X}=$ 92.61, $\mathrm{SD}=17.16$ ) within the low achieving groups; the obtained t value (0.246) was found not significant at 0.05 level with degree of freedom 304, ' $t$ ' critical value(1.960) being $>$ obtained ' $t$ ' value. It means that there was no variation in science anxiety of students within the low achieving groups with respect to their gender. Hence the null hypothesis (Ho2) was accepted.

\section{DISCUSSIONS AND IMPLICATIONS}

The findings of the present study that scienceanxiety exists among the participants. Students experience the phenomenon in and outside science classroom. There are students with high, moderate and low anxiety levels. Science anxiety easily surfaced out when students encountered situational scenario pertaining to different dimensions of measurement as mentioned earlier. The high science anxiety levels were found most against the dimension of 'fear of testing' in the population for both boys and girls compared to the other five dimensions. Most students frightened the situation of the examination hall, demonstration exams, viva-voce exams, answering a teacher's question and have hidden fear before every kind of assessments. It means they find examinations a tough tussle ground and anticipate the serious consequence upon failing. This feeling was very much evident through informal interactions with students. Interestingly, our finding reveals that it is the high achievers in science who experienced high levels of science anxiety. High achievers in science were found to be more science anxious than the low achievers on the dimension 'fear of testing', and 'content mastery' which indicates they feel pressurized in situations where they have to be judged on conceptual understanding. They were also found to be more anxious on the dimension 'performance in front of others' which means they feel tensed when they are being judged by others for their performance. Exceptionally low achievers in science were found more anxious on the dimension 'application of science' which implied that they were more uncomfortable in handling practical component of science than the high achievers. However, there was no significant difference observed between the high and low achievers on the dimensions of 'teachers' behaviour, teaching style and teaching environment' and 'parents' expectation' which suggests that in general the human association through the teaching-learning and familial environment does not effect the students according to their achievement levels. Also, gender influences one's performance in science according to present findings wherein girls at the secondary level are more science-anxious compared to their counterparts. High achieving girls were found to be more science anxious than the low achieving girls. The finding on gender is in agreement with one of the major binational studies by Kastrup and Mallow (2016). But our finding does not give us a reason to identify a 


\section{EPRA International Journal of Research and Development (IJRD)}

strong negative relationship between science anxiety level and science achievement of students, as observed in earlier findings. Rather there is a statistically significant positive relationship although of a very low magnitude. The scenario prevalent in the researched sample is indicative that science anxiety although a negative affect which at its high levels hinders high achievement in science, at its minimal threshold level contributes to improving achievement in science. It further implies that a less science anxious student may or may not perform well in science and vice-versa. Since high achievers were more science anxious, it compelled us to ask was it for any good? What could be the reason behind high anxiety of high achievers? Being anxious is being normal when it is within safe limits and can be controlled. It could be that its manifestation at minimal level stimulates students to compete in sciences and its absence brings down their performance levels. One can fairly construct knowledge in science if one is less science-anxious. However, the present finding also suggests that science-anxiety at a minimal threshold level are very obvious and may not strictly interfere with student's achievement in science. It is the high science anxiety levels which need to be given more attention as high science-anxious students fail to construct knowledge because their emotional state does not allow them. Science- anxiety is a universal phenomenon which is prevalent among school through university students. Science Anxiety is found to decrease from lower to higher grades (Czerniak \& Chiarelott, 1984). This can be partly because of students' gradual acquaintance to the subject and also partly because of the persistence of interest towards the subject all along. Studies of attitudes into school science show that children's attitudes towards science appear to become less positive as they progress through early stages of schooling, and become even less positive as they move on to higher levels which remains unclear (Koballa, 1995). It suggests by the time students reach higher grades they accept the fact that science is hot (modern terminology), hard, hostile and sometimes historically elite subject and they adjust with the requirement of being an ideal science student who is cognitively sound and emotionally inert. Often in doing so, they mask their emotions, pretending to be emotionally balanced and use coping strategies to resist emotional inclination. This is what the science students learn in the process of schooling conforming to contemporary science standards. What they fail to learn is that science is for all; science is an interactive discipline which needs constant engagement with the content and discourse on the environmental and social phenomenon, and that science learning is enhanced and supported by positive affect. Science anxiety has been documented in classrooms belonging to different cultural settings and is very much visible in both advanced societies and societies which aspire to be advanced. Kastrup-Mallow's (2016) bi-national study on Danish and American students raised many questions on contemporary practices of imparting and doing science. Their submission is to turn the table using a learner-friendly approach, where learners are constructing science experience in multiple perspectives and not just witnessing the laws of nature through the lens of their science teachers. They need to wear their glasses, observe for themselves and have the freedom and ease to present their logics. Here teachers need to take action by boycotting their expectations of rote memorization, mechanical thinking from students. Instead, they encourage them to reflect upon their own experiences and contextualize their science learning. Divergent thinking at the formal operational stage allows the learner to think of the problem in a holistic perspective (Kastrup \& Mallow, 2016). It is neither directed nor objective rather an amalgamation of different possibilities leading to the right conclusion. Students need to be taught about the importance of mistakes in doing science. Science teachers should shed away from their traditional fact presenting business. They should encourage students to find their answers to a given problem. Revolving around myths leads the way to facts. The teacher needs to address the core issue that science learning and teaching is exploratory and not just explanatory. Anxiety levels can be lowered if the teacher accepts that mistakes are very obvious in the path of exploration. In the easiness of explanation, something new and challenging can be introduced in the early years to make science learning interesting. The teacher is the product of the same educational system fails to resist the anxiety what she/he experienced in her/his science classroom and replicate it safely into her/his students. The whole disorder started through a modern version of school science which misinterprets the real nature of science. Students fail to learn science when science anxiety operates antagonistically to their learning requirement. Consequently, it materializes into a phobia towards science if it is not checked well in time. Science anxiety has been observed as a silently hidden hesitance towards science within students which is very troubling. We genuinely support the notion that science education in modern times has given rise to certain phobias which are not defining the real nature of science. Students are under stress for unnecessary reasons which should have not troubled them. They 


\section{EPRA International Journal of Research and Development (IJRD)}

feel science anxious when they do things without hands-on training, on being constantly compared to a set of standards, being forced to compete with their peers, and at times being labeled 'unfit for science' by their teachers. Teachers can improve upon students' science anxiety level by improvising their teachinglearning process of science. By improvisation, we refer to the involvement of learner's positive affects into the classroom experiences such as their happiness, interests, motivation, positive group behaviour interactions, self-confidence, temperament, selfefficacy and moods. We thus strongly believe involving affect in teaching and learning science will be a lifechanging experience for both teachers and learners which they will cherish for the rest of their lives. Science demands faith in its dynamic nature by doers of science and root of this faith lies in the passionate labour they put in their scientific endeavour which is never possible without involving one's emotions. Actually, affect is the artist behind the artistry of science.

\section{Declarations}

Funding - No funding

Conflicts of interest- Authors declare there is no conflict of interest.

Availability of Data and Material (data transparency)- Manuscript is supported with data which can be provided on request.

Acknowledgement

The authors want to acknowledge Czerniak \& Chiarelott whose scale was adapted for the present study.

\section{REFERENCES}

1. Alsop, S. (2001). Seeking emotional involvement in science education: Food-chains and webs. School Science Review, 83(302), 63-68.

2. Alsop, S. (2005) Bridging the cartesian divide: Science education and affect. In S. Alsop (Ed.), Beyond Cartesian dualism: Encountering affect in the teaching and learning of science (pp. 3-16). Dordrecht, The Netherlands: Springer.

3. Czerniak, C. \& Chiarelott, L. (1984, April). Science Anxiety: An Investigation of Science achievement, sex and grade level factors. Paper presented at the Annual Meeting of The American Educational Research Association, New Orleans, Louisiana.

4. Izard, C. E. (2002). Translating emotion theory and research into preventive interventions. Psychological Bulletin, 128(5), 796-824.

5. Kastrup, H. \& Mallow, V. J. (2016). Student attitudes, student anxieties and how to address them: A handbook for science teachers. San Rafael, CA: Morgan \& Claypool Publishers.
6. Kaya, E. \& Yildirim (2014). Science anxiety among failing students. Elementary Education Online, 13(2), 518-525.

7. Koballa, T. R. (1995). Children's attitudes towards learning science. In Glynn, S. M. and Duit, R. (eds.) Learning Science in the Schools. Research Reforming Practice (pp. 59-84). New Jersey: Lawrence Erlbaum Associates.

8. Mallow, J. V. (2010, October). Gender, science anxiety, and science attitudes: A multinational perspective. In Meeting of the United Nations Division for the Advancement of Women, United Nations Educational, Scientific and Cultural Organization (UNESCO), Paris, France.

9. Mallow, J. V. (1981). Science anxiety: Fear of science and how to overcome it. Thomond Press.

10. Mallow, J.V. \& Greenburg, S.L. (1983). Science anxiety and science learning. The Physics Teacher, 21(2), 95-99.

11. Watts, M. \& Alsop, S. (1997). A feeling for learning: modelling affective learning in school science. The Curriculum Journal, 8(3), 351-365.

12. Pekmn, R., Goetz, T., \& Titz, W. (2002). Academic emotions in students' self regulated learning and achievement: A program of quantitative and qualitative research. Educational Psychologist, 37, 91-106

13. Reiss, M. J. (2005). Importance of affect in science education. In S. Alsop (Ed.) Beyond Cartesian dualism: Encountering affect in the teaching and learning of science (pp. 17-25). Dordrecht, The Netherlands: Springer.

14. Alsop, S., \& Watts, M. (2003). Science education and affect. International Journal of Science Education, 25(9), 1043-1047.

15. Zembylas, M.(2005). Emotions and science teaching: present research and future agendas. In S. Alsop (Ed.) Beyond Cartesian dualism: Encountering affect in the teaching and learning of science (pp. 123-132). Dordrecht, The Netherlands: Springer.

16. Zembylas, M. (2002). Constructing genealogies of teachers' emotions in science teaching. Journal of Research in Science Teaching, 39, 79-103. 